\title{
Patogenitas Nematoda Entomopatogen Heterorhabditis spp. Terhadap Larva Spodoptera litura
}

\author{
Hawwa' Cahya Maulida ${ }^{1}$, Saiku Rokhim ${ }^{1}$, Erna Zahro’in ${ }^{2}$ \\ ${ }^{1}$ Program studi Biologi, Fakultas Sains dan Teknologi, Universitas Islam Negeri Sunan Ampel, \\ Jl. Ahmad Yani No.177, Surabaya, 60237 \\ ${ }^{2}$ Balai Besar Perbenihan dan Proteksi Tanaman Perkebunan Surabaya, \\ Jl. Raya Mojoagung No.52 Mojoagung, Jombang, 61482
}

Penulis untuk Korespondensi/E-mail: hawwacahya@gmail.com

\begin{abstract}
Spodoptera litura is a pest in vegetable plants that attacks the leaves and stems. Damage arising from the attack of $S$. litura can decrease the productivity of plants. Synthetic pesticides are often used in controlling the population of $S$. litura, but synthetic pesticides have a high negative impact. Potential entomopathogenic nematode Heterorhabditis spp. believed to be effective for controlling pest populations. This study aims to find out the pathogenic value of entomopathogenic nematode Heterorhabditis spp. to the larvae of $S$. litura. Based on the results obtained Heterorhabditis spp. has a positive influence in causing mortality in the larvae of $S$. litura. Heterorhabditis spp. mortality of up to $42 \%$. Symptoms indicated by larvae of $S$. litura affected by Heterorhabditis spp. among them the behavior becomes passive, the body becomes flaccid, the cuticle turns red and the tissues inside the body are destroyed. Obtained pathogenicity value Lc 50 Heterorhabditis $\mathrm{spp} .7,690 \mathrm{IJ} / \mathrm{ml}$, as for the factors affecting Heterorhabditis spp. such as humidity, temperature, $p H$, and light intensity.
\end{abstract}

Abstrak - Spodoptera litura merupakan hama pada tanaman sayur yang menyerang bagian daun dan batang. Kerusakan yang timbul akibat serangan $S$. litura dapat menurunkan produktifitas tanaman. Pestisida sintetik sering digunakan dalam mengontrol populasi $S$. litura, akan tetapi pestisida sintetik mempunyai dampak negatif yang tinggi. Potensi nematoda entomopatogen Heterorhabditis spp. diyakini efektif untuk mengendalikan populasi hama. Penelitian ini bertujuan untuk mengetahui nilai patogenitas nematoda entomopatogen Heterorhabditis spp. terhadap larva $S$. litura. Berdasarkan hasil yang diperoleh Heterorhabditis spp. mempunyai pengaruh yang positif dalam menimbulkan mortalitas pada larva $S$. litura. Heterorhabditis spp. dapat menimbulkan mortalitas hingga $42 \%$. Gejala yang ditunjukkan larva $S$. litura yang terserang Heterorhabditis spp. diantaranya perilaku menjadi pasif, tubuh menjadi lembek, kutikula berubah warna menjadi merah dan jaringan didalam tubuh hancur. Diperoleh nilai patogenitas Lc 50 Heterorhabditis spp. sebesar $7.690 \mathrm{IJ} / \mathrm{ml}$, adapun faktor yang mempengaruhi Heterorhabditis spp. seperti kelembaban, suhu, $p H$ dan intensitas cahaya.

Keywords - Entomopathogenic Nematodes, Pathogenicity, Spodoptera litura

\section{PENDAHULUAN}

Spodoptera litura atau ulat grayak merupakan
hama yang mempunyai jangkauan tanaman yang
luas, terlebih pada tanaman sayuran. Tanaman yang
terserang S. litura mempunyai gejala kerusakan
seperti batang dan daun berlubang, sobek hingga
tersisa epidermis dan tulang daun saja. Kerusakan
yang ditimbulkan ini akan berakibat pada penurunan
produktifitas tanaman dan kegagalan panen [1].
Fase hidup S. litura termasuk kedalam metamorfosis sempurna, yaitu mengalami stadia telur, larva, pupa dan imago [2].

Spodoptera litura dapat mengasilkan telur sebanyak 3000 butir yang akan menetas setelah 3-5 hari. Stadium Larva pada $S$. litura terbagi menjadi lima instar dengan warna tubuh hijau muda dengan bagian sisi berwarna coklat tua pada instar awal. Pada saat instar akhir terdapat corak kalung 
berbentuk bulan sabit dengan warna hitam pada segmen abdomen keempat dan kesepuluh. Tingkat nafsu makan $S$. litura pada stadia instar sangat tinggi terlebih saat menginjak instar 3. Larva S. litura akan mengalami fase pupa selama 8-11 hari dengan warna pupa coklat kemerahan. Pupa kemudian menetas menjadi imago atau ngengat. Imago $S$. litura mempunyai warna sayap coklat pada bagian depan dan putih keperakan dibagian sayap belakang dengan motif berak-bercak kehitaman [2].

Penggunaan pestisida sintetik merupakan salah satu upaya untuk mengendalikan populasi S. litura, akan tetapi pestisida sintetik mempunyai dampak negatif yang besar. Penggunaan pestisida sintetik yang berlebihan dan tidak sesuai dosis akan meningkatkan resistensi hama. Selain itu juga berdampak buruk bagi lingkungan dan makhluk hidup di sekitarnya [3]. Melihat besarnya dampak negatif yang ditimbulkan pestisida sintetik maka berkembanglah inovasi baru berupa agen pengendali hayati. Agen pengendali hayati merupakan makhluk hidup yang dimanfaatkan untuk mengendalikan organisme pengganggu tanaman, karena mempunyai kemampuan menimbulkan mortalitas pada makhluk hidup lain. Salah satu contoh dari APH adalah nematoda entomopatogen [4].

Nematoda entomopatogen berasal dari 2 genus yaitu Heterorhabditis spp. dan Steinernema spp. Kedua genus NEP tersebut dapat menimbulkan mortalitas pada larva serangga dengan bantuan bakteri yang terkandung dalam intestinumnya. Nematoda Heterorhabditis spp. bersimbion dengan bakteri Photorhabdus spp. sedangkan Sterinernema spp. bersimbion dengan bakteri Xenorhabdus spp. [5]. Hubungan NEP dan bakteri simbion termasuk kedalam simbiosis mutualisme. Nematoda entomopatogen memperoleh lingkungan yang mendukung untuk berkembangbiak serta nutrisi yang tercukupi dari jaringan larva yang hancur. Bakteri simbion menggunakan NEP sebagai media untuk mendapatkan inang tanpa dipengaruhi faktor lingkungan yang kurang mendukung [6].

Penggunaan NEP sebagai pengendali hayati dinilai lebih efektif, karena tidak menimbulkan resisten pada hama, tidak mencemari lingkungan serta aman bagi mamalia. Selain itu NEP mampu menginfeksi inang secara cepat, berkisar antara 24-48 jam setelah aplikasi [7]. Nematoda entomopatogen juga mempunyai jangkauan inang yang luas, khususnya pada ordo Lepidoptera. Selain itu juga dapat efektif di beberapa ordo Coleoptera dan Diptera [8]. Penelitian ini bertujuan untuk mengetahui nilai patogenitas nematoda entomopatogen Heterorahbditis spp. terhadap larva S. Litura

\section{METODE}

\section{Desain, Tempat dan Waktu}

Penelitian ini dilakukan pada bulan Juli 2019 bertempat di Laboratorium Bakteriologi Balai Besar Perbenihan dan Proteksi Tanaman Perkebunan (BBPPTP) Surabaya. Penelitian ini termasuk ke dalam penelitian eksperimental dengan rancangan acak lengkap. Variabel bebas dalam penelitian ini adalah pemberian perlakuan berupa konsentrasi nematoda entomopatogen, sedangkan variabel terikatnya adalah mortalitas dari larva $S$. litura. Terdapat 5 perlakuan dengan 4 kali ulangan, adapun pemberian perlakuan diantaranya $0 \mathrm{IJ} / \mathrm{ml}(\mathrm{P} 0), 100$ $\mathrm{IJ} / \mathrm{ml}$ (P1), $200 \mathrm{IJ} / \mathrm{ml}$ (P2), $250 \mathrm{IJ} / \mathrm{ml}$ (P3) dan 300 $\mathrm{IJ} / \mathrm{ml}(\mathrm{P} 4)$.

\section{Alat dan Bahan}

Alat yang digunakan dalam penelitian ini diantaranya adalah cawan petri berdiameter $9 \mathrm{~cm}$, bekker glass, kertas saring, pinset, mikro pipet, pipet tetes, plastik wrap dan label. Sedangkan bahan yang digunakan adalah nematoda Heterorhabditis spp. yang dikembang biakan secara in vivo oleh Balai Besar Perbenihan dan Proteksi Tanaman Perkebunan (BBPPTP) Surabaya, Larva S. litura instar 3 yang dikembangbiakkan oleh Balai Penelitian Pemanis dan Serat (BALITAS) Malang, akuades steril dan alkohol $70 \%$.

\section{Tahapan Penelitian}

Larva S. litura instar 3 sebanyak 10 ekor dimasukan kedalam cawan petri kecil yang telah diisi dengan kertas saring. Nematoda entomopatogen kemudian diaplikasikan sesuai dengan konsentrasi yang telah ditentukan. Dilakukan pengamatan pada 24 JSA, 48, JSA, 72 JSA, 96 JSA dan 120 Jam setelah aplikasi. Adapun parameter pengamatan diantaranya, gejala larva S. litura terserang Heterorhabditsis spp., persentase mortalitas larva $S$. litura dan nilai patogenitas nematoda.

Pengamatan gejala serangan NEP Heterorhabditis spp. dilakukan secara makroskopis dengan melihat perubahan perilaku, bentuk tubuh dan warna pada larva $S$. litura Persentase mortalitas larva $S$. litura yang mati dihitung menggunakan rumus sebagai berikut,

$$
\text { Mortalitas }=\frac{\sum \text { larva yang mati }}{\sum \text { larva uji }}
$$


Apabila terjadi kematian pada perlakuan kontrol yang tidak lebih dari $20 \%$ maka dilakukan perhitungan menggunakan rumus Abbot berikut ini,

$$
\mathrm{Pt}=\frac{P o-P c}{100-P c} \times 100 \%
$$

Keterangan:

$\mathrm{Pt}=$ Banyaknya larva yang mati setelah dikoreksi

$\mathrm{Po}=$ Persentase banyaknya larva yang mati pada perlakuan

$\mathrm{Pc}=$ Persentase banyaknya larva yang mati pada control

Data persentase mortalitas yang telah diperoleh kemudian di olah menggunakan analisis probit guna menentukan nilai patogenitas Lc 50 nematoda entomopatogen Heterorhabditis spp. terhadap larva S. litura

\section{Pengolahan dan Analisis Data}

Data yang diperoleh merupakan nilai mortalitas pada larva S. litura. Data kemudian diuji secara statistik menggunakan Software SPSS 25. Dikarenakan data yang diperoleh tidak terdistribusi normal dan tidak homogen maka akan diuji secara non parametrik menggunakan uji Kruskal-Wallis dan MannWhitney. Uji Kruskal-Wallis dilakukan untuk mengetahui pengaruh pemberian NEP Heterorhabditis spp. terhadap mortalitas S. litura sedangkan uji Mann Whitney untuk mengetahui konsentrasi yang paling berpengaruh.

\section{HASIL DAN PEMBAHASAN}

\section{Gejala Serangan NEP Heterorhabditsis spp. Terhadap Larva $S$. litura}

Hasil pengamatan menunjukan bahwa pengaplikasian Heterorhabditis spp. membuat $S$. litura berubah menjadi hiperaktif dan selang beberapa lama menjadi lebih pasif. Hal ini dikarenakan nematoda entomopatogen mulai menginfeksi tubuh $S$. litura. Perilaku pasif menunjukan adanya penurunan metabolisme pada $S$. litura karena hancurnya jaringan didalam tubuh [9]. Gejala lain yang terlihat adalah perubahan warna kutikula menjadi merah kehitaman, tubuh menjadi lunak, jaringan tubuh hancur hingga tersisa epidermis saja. Gejala yang terlihat ini sejalan dengan penelitian yang dilakukan oleh [6] bahwa larva serangga yang terinfeksi NEP Heterorhabditis spp. akan berubah warna menjadi merah kehitaman, tekstur tubuh menjadi lunak dan jaringan hancur.

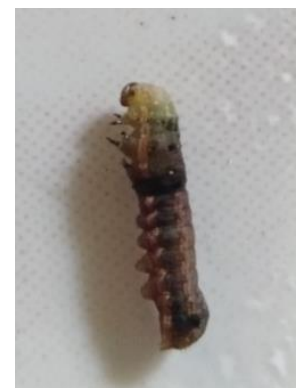

Gambar 1. Larva S. litura mati akibat Heterothabditis spp.

Nematoda Heterorhabditis spp. Masuk kedalam tubuh $S$. litura dengan melakukan penetrasi melalui lubang-lubang alami seperti mulut, spirakel dan anus. Selain itu dapat pula masuk melewati kutikula dan epidermis, hal ini dikarenakan nematoda Heterorhabditis spp. mempunyai tonjolan gigi dorsal pada bagian anterior yang dapat merobek epidermis ataupun kutikula pada larva S. litura ([7]; [10]) Ketika penetrasi, terjadi perubahan perilaku larva $S$. litura menjadi bergerak tidak beraturan. Perilaku ini juga terlihat pada penelitian yang dilakukan oleh [9] yang mengaplikasikan NEP ke larva $O$. rhinoceros, dimana perilaku larva $O$. rhinoceros berubah menjadi hiperaktif setelah pengaplikasian nematoda entomopatogen. Perilaku tersebut menunjukan adanya perlawanan oleh $S$. litura dalam menghadapi infeksi Heterorhabditis spp. Sistem imun $S$. litura akan membentuk sebuah kapsul terbuat dari hemosit yang akan mengurung Heterorhabditis spp. Nematoda entomopatogen Heterorhabditis spp dapat bertahan dengan mengeluarkan enzim ekstraseluler untuk mengurangi jumlah hemosit serangga ([9]; [10]).

Ketika Heterorhabditis spp. telah sampai di hemocoel selanjutnya Heterorhabditis spp. akan mengeluarkan bakteri simbion yang terkandung dalam intesitum. Bakteri simbion Photorhabdus spp. selanjutnya menghasilkan entomotoksin berupa protease, lipase, DNAse, lipopolisakarida, lechitinase dan sisa hasil metabolisme yang berakibat pada rusaknya jaringan tubuh. Rusaknya jaringan tubuh ini akan berakibat pada kematian larva [11]. Entomotoksin yang dihasilkan Photorhabdus spp. juga berakibat pada perubahan warna kemerahan pada kutikula larva yang terserang NEP Heterorhabditis spp. Perubahan tersebut terjadi karena bakteri simbion Photorhabdus spp. Mempunyai kemampuan bioluminescence, yaitu dapat memancarkan cahaya [12]. 


\section{Presentase Mortalitas Larva S. litura}

Dapat dilihat dalam Tabel 1. Pada 24 jam setelah aplikasi menunjukan adanya mortalitas pada $S$. litura perlakuan P4 (300 IJ/ml) sebanyak $5 \%$, sedangkan pada perlakuan lainya masih belum terjadi mortalitas. Pada 48 jam setelah aplikasi mortalitas terjadi pada perlakuan P3 sebesar 12\%, pada perlakuan $\mathrm{P} 4$ mortalitas tidak bertambah yaitu $5 \%$. Pada perlakuan P0, P1 dan P2 belum terlihat mortalitas. Hasil mortalitas yang diperoleh membuktikan bahwa pengaplikasian nematoda Heterorhabditis spp. dapat menimbulkan mortalitas setelah 24-48 jam setelah aplikasi, yang berarti dalam kurun waktu tersebut NEP Heterorhabditis spp sudah berada dalam hemochoel serangga dan mengeluarkan bakteri simbion [5].

Tabel 1. Persentase Mortalitas Larva S. litura

\begin{tabular}{lccccc}
\hline Perlakuan & \multicolumn{5}{c}{ Mortalitas $\%$} \\
& 24 & 48 & 72 & 96 & 120 \\
& JSA & JSA & JSA & JSA & JSA \\
\hline P0 & 0 & 0 & 0 & 0 & 0 \\
\hline P1 & 0 & 0 & 0 & 0 & 14 \\
\hline P2 & 0 & 0 & 0 & 0 & 16 \\
\hline P3 & 0 & 12 & 28 & 30 & 42 \\
\hline P4 & 5 & 5 & 5 & 5 & 10 \\
\hline
\end{tabular}

Pada 72 jam setelah aplikasi hanya perlakuan P3 yang mengalami penambahan mortalitas menjadi $28 \%$. Mortalitas pada perlakuan P4 tetap pada 5\% dan P0, P1 serta P2 tetap pada $0 \%$. Belum terjadinya mortalitas pada perlakuan P1 dan P2 dikarenakan tedapat sistem imun serangga yang memberikan perlawanan terhadap infeksi nematoda. Sehingga nematoda tidak bisa mencapai hemochoel untuk mengeluarkan bakteri simbion [9]. Pada 96 jam setelah aplikasi mortalitas juga tidak mengalami perubahan yang signifikan hanya pada perlakuan P3 saja yang mengalami penambahan menjadi $30 \%$.

Setelah 120 jam setelah aplikasi terlihat mortalitas yang terjadi pada semua perlakuan kecuali perlakuan P0 (kontrol) sebesar 0\%. Terlihat perlakuan P1 terjadi mortalitas $14 \%$ dan P2 sebesar $16 \%$. Pada perlakuan P3 dan P4 mengalami penambahan kembali, yaitu P3 menjadi $42 \%$ dan P4 menjadi 10\%. Nilai mortalitas lebih besar terlihat pada perlakuan P3 (250 IJ/ml) daripada perlakuan P4 (300 $\mathrm{IJ} / \mathrm{ml}$ ), selain mengahdapi sistem imun serangga nematoda juga dihadapkan oleh kompetisi antar individu. Semakin banyak jumlah nematoda yang diaplikasikan maka semakin besar juga persaingan antar individu dalam memperebutkan makanan dan tempat tinggal. Sehingga mengakibatkan kematian pada nematoda Heterorhabditis spp. [13]. Hasil yang sama diperoleh pada penelitan [14] yang mendapatkan hasil, konsentrasi 750IJ menimbulkan nortalitas lebih banyak daripada konsentrasi 1000 $\mathrm{IJ} / \mathrm{m}$ yaitu sebesar $45,60 \%$

Dari uji statistik non parametrik didapatkan hasil nilai Sig 2 tail uji Kruskal-Wallis sebesar 0,025 atau kurang dari 0,05 , apabila nilai sig kurang dari maka terdapat pengaruh dalam pengaplikasian NEP Heterorhabditis spp. Terhadap mortalitas S. litura. Dikarenakan terdapat pengaruh maka dilanjutkan dengan uji Mann Whitney.berikut ini hasil dari uji Mann Whitney,

Tabel 2. Hasil Uji Mann Whitney

\begin{tabular}{llllll}
\hline & P0 & P1 & P2 & P3 & P4 \\
\hline P0 & & & & & \\
\hline P1 & 0,136 & & & \\
\hline P2 & 0,136 & 0,906 & & \\
\hline P3 & $0,005^{*}$ & $0,049^{*}$ & 0,107 & & \\
\hline P4 & 0,136 & 0,906 & $0,013^{*}$ & $0,013^{*}$ & \\
\hline
\end{tabular}

Berdasarkan hasil uji Mann Whitney (Tabel 2) terdapat beberapa perlakuan yang mempunyai pengaruh signifikan dalam menimbulkan mortalitas larva S. litura, yaitu perlakuan yang ditandai dengan adanya tanda bintang pada bagian akhir angka. Adapun perlakuan tersebut diantaranya, P0:P3; P1:P3; P2:P4 dan P3:P4. Langkah selanjutnya adalah menghitung nilai Lc 50 menggunakan analisis probit

\section{Uji Patogenitas NEP Heterorhabditsis spp. Terhadap Larva $S$. Litura}

Nilai lethal concentration 50 (Lc50) merupakan konsentrasi yang dapat menyebabkan mortalitas $50 \%$ dari total larva uji. Berdasarkan hasil analisis probit didapatkan nilai Lc 50 sebesar 7,690 IJ/ml. Penentuan Nilai Lc50 dimaksudkan agar NEP Heterorhabditis spp. yang diaplikasikan dapat efektif mengontrol populasi $S$. litura konsentrasi yang berlebihan akan mengakibatkan terjadinya kompetisi antar individu. Selain itu nematoda merupakan makhluk hidup yang dapat berkembang biak sehingga mempunyai sifat yang berkelanjutan [13].

Adapun faktor yang dapat mempengaruhi kinerja NEP Heterorhabditis spp. adalah kelembaban, suhu, cahaya dan $\mathrm{P} h$. Nematoda entomopatogen dapat menjangkau inang dengan bantuan air apabila kelembaban pada lingkungan sekitar rendah maka NEP akan kesulitan dalam menjangkau inang [15] Suhu lingkungan yang dapat membantu NEP menjangkau inang berkisar antara $8-35^{\circ} \mathrm{C}$ dan 
optimal pada suhu $25^{\circ} \mathrm{C}$. Apabila suhu lingkungan tinggi akan menyebabkan nematoda mati, sedangkan suhu yang terlalu rendah akan menyebabkan nematoda inaktif ([16]; [17]). Nematoda entomopatogen juga sensitif akan sinar uv pada sinar matahari langsung, hal ini akan menyebabkan penurunan aktivitas. Dalam pengaplikasian nematoda sebaiknya dilakukan pada saat sore hari dimana sinar matahari tidak terlalu terang. Ph optimal yang dimiliki NEP berkisar antara 7-8, viabilitas nematoda entomopatogen akan menurun apabila $\mathrm{P} h$ terlalu asam atau basa ([7]; [14]; [18]).

\section{KESIMPULAN}

Pengaplikasian Heterorhabditis spp. mempunyai hasil yang positif terhadap mortalitas larva S. litura. Larva S. litura yang terserang Heterorhabditis spp. menunjukan perilaku pasif, perubahan warna kutikula menjadi kemerahan, tubuh menjadi lunak dan jaringan dalam hancur. Nematoda entomopatgen Heterorhabditis spp. dapat menimbulkan mortalitas dari 24 jam setelah aplikasi, dengan nilai mortalitas tertinggi sebesar $43 \%$ pada perlakuan P4. Didapatkan nilai patogenitas Lethal concentration 50 (Lc 50) sebesar $7.690 \mathrm{IJ} / \mathrm{ml}$.

\section{UCAPAN TERIMA KASIH}

Penulis mengucapkan banyak terimakasih kepada Ibu Erna Zahro'in yang telah membimbing dan memberikan Dana dalam penelitian ini. Penulis juga berterimakasih kepada semua pihak yang telah membantu yang tidak dapat disebutkan satu-persatu.

\section{REFERENSI}

[1] F. Dwimartina, R. Rostaman, dan L. Soesanto, "Keefektifan Bakteri Serratia Endosimbion WBC Terhadap Ulat Grayak (Spodoptera litura F.) Di Laboratorium Entomologi BBPOPT Jatisari Karawang," Agro Wiralodra, vol. 3, no. 1, hal. 29-35, 2020, doi: 10.31943/agrowiralodra.v3i1.39.

[2] Z. A. Amin, T. Wardhani, dan S. Pratamaningtyas, "Pengaruh Metode Maserasi Jazzar Dan Balafif Dalam Memperoleh Ekstrak Air Daun Mindi (Melia azedarach L.) Sebagai Insektisida Botani Pada Ulat Grayak (Spodoptera litura F.)," J. Pertan. 2016, vol. 10, no. 2, hal. 110-121, 2016.

[3] Badaruddin, D. Fitriyanti, dan Susilawati,
"Pelatihan Pembuatan Pestisida Hayati Ramah Lingkungan Di Kampung Sayur Kelurahan Landasan Ulin Utara Banjarbaru," in Prosiding Seminar Nasional Pengabdian Kepada Masyarakat, 2020, vol. 2, hal. 15-20.

[4] A. Ibrahim, Yulistiawati A.S. Jasil, A. Rosyad "Agen Hayati Pemacu Pertumbuhan Dan Pengendali Penyakit Tertular Benih Beberapa Tanaman Pangan Dan Hortikulurai," Bul. Inov. Pertan. Spesifik Lokasi, vol. 6 no. 2, hal. 169 76, 2019.

[5] H. Afifah, L., Rahardjo B.T. dan Tarno, "Eksplorasi Nematoda Entomopatogen pada Lahan Tanaman Jagung, Kedelai, dan Kubis di Malang serta Virulensinya terhadap Spodoptera litura Fabricius," J. HPT, vol. 1, no. 2, hal. 1-9, 2013.

[6] Suyadi, Rosfiansyah, J. Nurdiana, A. Suryadi, Sopialema dan S.Waluyo "Studi Genera Nematoda Entomopatogen Pada Lahan Lebak Padi Sawah ( $O r y z z a s$ a $t i v a$ L.) Di Kecamatan Muara Wis Kabupaten Kutai Kartanegara," in Konferensi Antarabangsa Islam Borneo Ke-10 2017, 2017, September, hal. 500-507.

[7] G. Indriati and I. Trisawa, "Nematoda Patogen Serangga Heterorhabditis spp. Untuk Pengendalian Hama Penggerek Batang Lada," J. Ind. Beverage Crop., vol. 2, no. 3, hal. 291296, 2011.

[8] W. Widayati, "Uji Efikasi Nematoda Entomopatogen Pada Hama Tanaman Cabai," Agritrop J. Ilmu-Ilmu Pertan., hal. 63-66, 2012.

[9] S. Khairunnisa, M. I. Pinem. dan F. Zahra "Uji Efektifitas Nematoda Entomopatogen Sebagai Pengendali Penggerek Pucuk Kelapa Sawit (Oryctes rhinoceros L.) (Coleoptera: Scarabaidae) Di Laboratorium," J. Online Agroekoteknologi, vol. 2, no. 2, hal. 1-2, 2014.

[10] B. T. Rahardjo, H. Tarno, and L. Afifah, "Efikasi Nematoda Entomopatogen Heterorhabditis sp. isolat Lokal Terhadap Diamond Back Moth Plutella xylostella," J. $H P T$, vol. 2, no. 2, hal. 1-8, 2014.

[11] S. Shan. H. Ma, Y. Li, C. Huang, X. Gu, Z. Jiang, B. Sun, C. Chen, X. Wei, G. Shen. D. Shapiro-Ilan dan W. Ruan., "Metabolites From Symbiotic Bacteria Of Entomopathogenic Nematodes Have Antimicrobial Effects Against Pythium myriotylum," Eur. J. Plant Pathol., vol. 158, no. 1, pp. 35-44, 2020, doi: 10.1007/s 10658-020-02053-2.

[12] F. L. Inman, S. Singh, dan L. D. Holmes, "Mass Production of the Beneficial Nematode 
Heterorhabditis bacteriophora and Its Bacterial Symbiont Photorhabdus luminescens," Indian J. Microbiol., vol. 52, no. 3, pp. 316-324, 2012, doi: 10.1007/s12088-012-0270-2.

[13] P. Widiyaningrum, N. dan Subekti, dan B. Priyono, "Uji Patogenitas Nematoda Entomopatogen Isolat Semarang Steinernema sp Pada Rayap Tanah Macrotermes sp," in Prosiding Semnas Hasil Penelitian., 2016, hal. 178-182.

[14] A. B. Satria, P. Widiyaningrum, and S. Ngabekti, "Viabilitas Dua Isolat Lokal Nematoda Entomopatogen pada Berbagai Variasi pH," Life Sci., vol. 7, no. 1, hal. 9-15, 2018.

[15] M. Zart et al., "Performance of Entomopathogenic Nematodes On The Mealybug, Dysmicoccus brevipes (Hemiptera: Pseudococcidae) And The Compatibility Of Control Agents With Nematodes," J. Nematol., vol. 53, pp. 1-10, 2021, doi: 10.21307/JOFNEM-2021-020.
[16] M. Lortkipanidze, K. Hwseynov, M. Kokhia, O. Gorgadze, and M. Kuchava, "Effect of Temperature on the Virulence of Entomopathogenic Nematodes," Adv. Ecol. Environ. Res., pp. 32-38, 2019.

[17] I. G. A. A. Indrayani and S. dan Chaerani, "Patogenisitas Nematoda Entomopatogen Terhadap Hama Uret Tebu Lepidiota stigma (Coleoptera: Scarabaeidae)," Bul. Plasma Nutfah, vol. 24, no. 2, hal. 83-88, 2018.

[18] D. R. Indriyanti, N. F. Awalliyah, and P. Widiyaningrum, "Perbanyakan Nematoda Entomopatogen ( Nep ) Pada Berbagai Media Buatan Entomopathogenic Nematodes (Enps) Rearing," Sainteknol J. Sains Dan Teknol., vol. 13, hal. 9-16, 2015. 